\title{
Introducing a Cross-Course Teaching Innovation to Enhance Group Project Performance
}

\section{DeFanti, Mark}

Providence College, USA.

\begin{abstract}
Marketing educators and students recognize the benefits derived from group assignments. Nonetheless, serious problems that occur frequently in student groups are diminished effort by some free-riding team members or disassociation from the group by lone wolf team members. In a highly innovative manner, the American Marketing Association's integrated marketing plan international competition was concurrently adopted by Principles of Marketing, Marketing Research and Advanced Advertising courses in an attempt to leverage the many benefits of team projects while minimizing their drawbacks. Empirical evidence suggests that group performance may be enhanced when lone wolf group members who possess a greater level of expertise to that of their peers are present.
\end{abstract}

Keywords: lone wolf students; free riders; group project performance 


\section{Introduction}

Anecdotal evidence suggests that many of the marketing principles learned in the Principles of Marketing course are forgotten before students enroll in subsequent courses such as Consumer Behavior, Promotional Strategy, International Marketing, Marketing Research and Marketing Capstone. By introducing a comprehensive integrated marketing plan into the course, it is hoped that by applying these principles, students will retain their knowledge of them for a longer period of time.

\section{Literature Review}

\subsection{Benefits of Group Assignments}

Without question, marketing educators recognize the benefits derived from group assignments (Williams et al. 1991). First and foremost, they help to achieve the learning objectives in a marketing course (Henke et al. 1988). Moreover, past research in the education field suggests important advantages to group assignments that are perhaps less widely appreciated (Williams et al. 1991). Past research suggests that there exist a broad range of benefits for students participating in theoretical student-led group projects for real companies (e.g., Dommeyer 1986; Hansen 2006; Henke 1985; Henke et al. 1988; Parsons and Lepkowska-White 2009; Slavin 1990; Williams et al. 1991). For instance, they provide students with comprehensive, realistic experiences in marketing, and can develop other essentials of the workplace such as communication skills (Williams et al. 1991). Because they are oriented to marketing careers, group projects motivate students more effectively than individual assignments (Williams et al. 1991). They also give students the opportunity to experience the full complexity of marketing problems (Henke 1985; Henke et al., 1988).

Students in both theoretical and client sponsored group projects found them to be challenging, effective, practical, and intense; to build more interest in the course; and to help them apply the concepts studied in class to real life situations while giving them hands on experience and granting them an ability to see what they have learned (Parsons and Lepkowska-White 2009).

\subsection{Challenges of Group Assignments}

Notwithstanding the value of group assignments in marketing education, they can present significant drawbacks (Strong 1988). A serious problem that occurs frequently in student groups is diminished effort by some free-riding members (e.g., Abernethy and Lett 2005; Beard et al. 1989; Bosley 1990; Dommeyer 2007, 2012; Latane, Williams and Harkins 1979; Strong and Anderson 1990; Tyagi 2010) or disassociation from the group by "lone wolf" team members (Barr et al. 2005; Dixon et al. 2003). Finally, team projects frequently fail to provide the intended learning experience for a variety of reasons, among them 
students' lack of effective interpersonal and small group skills, which leads to counterproductive group conflict (Forman and Katsky 1986; Johnson and Johnson 1987; Kohn 1986).

\section{Teaching Innovation}

In order to take advantage of the numerous benefits offered by group projects while attempting to avoid the aforementioned difficulties faced by students and faculty of working with actual clients, in a highly innovative manner, the American Marketing Association's integrated marketing plan international competition for eBay was concurrently adopted by principles of marketing, marketing research and advanced advertising courses in an attempt to leverage the many benefits of team projects while minimizing their drawbacks. The semester long group project in the three courses helped students gain factual knowledge about marketing such as terminology, classifications, methods, and trends; learn to apply the course material; and develop specific skills, competencies, and points of view needed by professionals in the field of marketing management.

The Principles of Marketing course helped students understand fundamental marketing concepts, theories, and principles with respect to external and internal environmental forces; understand fundamental marketing concepts, theories, and principles with respect to market and buyer behavior; understand fundamental marketing concepts, theories, and principles with respect to product (goods, services and ideas), distribution, pricing, and promotion decisions; recognize ethical problems related to marketing activities; and identify the major components of the environment for international marketing and describe various methods and strategies for entering foreign markets.

The Marketing Research course was designed to study research methodology and its application to the solution of marketing problems. Procedures and analytical tools were examined. This course familiarized students with the role of marketing research, designing research studies, measurement, sampling and statistical theory, and analysis and reporting. Upon successful completion of the Marketing Research course, the students were able to create a survey, demonstrating both an ability to construct items and assess validity; analyze data, demonstrating both an ability to understand and apply statistical toolsconduct a focus group, demonstrating both an ability to moderate and conduct a focus group; report research results, demonstrating both an ability to present a written and oral research report; and understand fundamentals about experimental design, demonstrating both an understanding of testing and demonstrating causality.

The Advanced Advertising course familiarized students with the role of advertising as an activity in a firm's marketing mix, the organization and process of advertising activity, advertising media, advertising campaigns, advertising methods in major media, advertising 
research, cost analysis, and ethics-related issues. It was an advanced course that imparted a breadth of knowledge as well as a specialized depth of knowledge. In addition, the course introduced the students to four major parts of advertising: the process of advertising, the planning of advertising, preparing the advertising message, and placing the advertising message. The course was focused on the attainment of skills necessary for students to advance in their professional lives. These skills included creativity, critical thinking and the evaluation and creation of effective advertising communications, among others.

Finally, all three courses aim to help the students gain progress toward achieving the four undergraduate learning goals. First, students will build on the liberal arts core to demonstrate an ability to think critically and make business decisions that appreciate the need to balance the often conflicting demands of the marketplace, the global environment and society. Second, students will communicate effectively, using technology when appropriate. Third, students will demonstrate ongoing development of and strengthened skills in interpersonal relationships and teamwork. Fourth, students will understand the importance of behaving ethically in their professional lives.

The American Marketing Association provides a comprehensive competition guide, which outlines the deliverables expected from the students, along with several financial summaries of vitaminwater's performance in sales and market share, which avoided the problem of incomplete financial information often faced in client-sponsored projects (Parsons and Lepkowska-White 2009). From this project, students learned how to use secondary market research to perform a situation analysis; to conduct primary marketing research; to segment a market, identify a proper target market and position its brand toward that target market; devise a marketing strategy and tactics; and to propose how they would measure and evaluate their integrated marketing plan. The students were given a $\$ 10$ million budget to market eBay in the U.S. over a 16-month period beginning Septemner 2016 and they were required to provide a 16-month sales forecast for their marketing strategy along with an additional four years of sales projections based on a continuation of their strategy while documenting their assumptions.

To a large extent, however, the problem of inequitable contributions was solved with a grading system that gave appropriate weight to individual contributions, as well as to the group's achievement (Williams et al. 1991). In doing so, it satisfied the necessity for individual accountability (Williams et al. 1991). To ensure students' achievement (based on course objectives), the reward structure motivated students to engage in effective group processes as well as to produce a quality product (Williams et al. 1991). The team assignment combined individual accountablility with a group goal (Johnson and Johnson 1986; Slavin 1990; Webb 1982). The team assignment was an interdependent task, a cooperative goal that a student was able to achieve only insofar as the group achieved its goal (Williams et al. 1991). Such a structure provided an incentive for students to help their 
fellow students learn, even to bring the slower ones along, and was the key to making the group project a fully cooperative learning experience (Williams et al. 1991). Students' individual achievement was monitored through numerous student meetings the professor both in class and out of class (Williams et al. 1991; Larson and LaFasto 1989). These meetings took place both on an individual basis and a functional team basis with students acting as account executives, publicists, media planners, researchers, artists and copy writers. Meeting minutes (Bogert and Butt 1990; Larson and LaFasto 1989), individual logs (Goldstein and Malone 1984; Nezlek et al. 1983) as well as mid-term and end of term peer evaluations (Williams et al. 1991; Darian 1988; Dommeyer 1986) accompanied by confidential memos (Williams et al. 1991) were collected from the students. In addition, the professor reserved the right to "fire" a student from the group at the mid-term if a student's peer evaluations indicated excessive free riding (Abernethy and Lett 2005).

\section{Results}

Consistent with previous research regarding the academic benefit of using American Marketing Association competitions (Aurand et al. 2012), the project did indeed encourage team members to help each other learn (Williams et al. 1991) both inside and outside of class. By spending over 100 hours per person on the project outside of class, 196 students (75 males and 121 females) on 23 teams exhibited extraordinary depth of thought and mastery of course content by applying over 100 terms from their textbook in their final projects. The top-ranked team was comprised of one senior female student enrolled in Advanced Advertising and Marketing Research concurrently as well as six freshman students (3 males and 3 females) enrolled in Principles of Marketing and a female sophomore mentor who had completed the project as a freshman. Competing against over 100 other universities from around the world, this team placed $10^{\text {th }}$ overall as a semifinalist and surpassed teams from highly ranked universities such as Carnegie Mellon University, Indiana University, University of Georgia, University of Maryland, University of Texas at Austin, and University of Washington to name a few.

The students' learning is also evidenced by satisfactory performance on their chapter quizzes and final exam. Given that lectures were replaced with in-class exercises related to the project, this is an important point. Specifically, on the final exam, the students correctly answered $60 \%$ of the 30 questions that the northeastern liberal arts college has used for its AACSB Assurance of Learning assessment. While this is below the $70 \%$ answered correctly by students in other lecture-based principles of marketing classes in previous years, this is an acceptable outcome considering that students individually spent between a required miniumum of 100 hours on the project. Another interesting finding is that the students performed consistently well on the most difficult questions offered by the Kotler and Armstrong (2016) test bank. 
Drawbacks to this method include lower performance on the aforementioned common final exam questions as well as lower student satisfaction with the course as evidenced by the students' comments. Overall, these findings are consistent with the results of Bacon (2005), which indicated that students in a consumer behavior course learned less of the project-related content (measured with multiple choice and short answer questions) than did students who completed a shortened version of the project individually.

\section{Conclusion}

Marketing educators and students recognize the benefits derived from group assignments. Nonetheless, serious problems that occur frequently in student groups are diminished effort by some free-riding team members or disassociation from the group by lone wolf team members. In a highly innovative manner, the American Marketing Association's integrated marketing plan international competition was concurrently adopted by Principles of Marketing, Marketing Research and Advanced Advertising courses in an attempt to leverage the many benefits of team projects while minimizing their drawbacks. Empirical evidence suggests that group performance may be enhanced when lone wolf group members who possess a greater level of expertise to that of their peers are present.

\section{References}

Abernethy, A.M. \& Lett, W. L. III (2005). You are fired! A nethod to control and sanction free riding in group assignments. Marketing Education Review, 15(1), 47-54.

Aurand, T.W., St. Clair, J.S. \& Sullivan, U. (2012). Analyzing the impact of the 2012 Ford Focus target hunt: Can student managed projects accomplish both academic and corporate objectives?" Journal of International Education Research, 8(3), 233-242.

Bacon. D.R. (2005). The effect of group projects on content-related learning. Journal of Management Education, 29(2), 248-267.

Barr, T.F., Dixon, A.L. \& Gassenheimer, J.B. (2005). Exploring the 'lone wolf' phenomenon in student teams. Journal of Marketing Education, 27, 81-90.

Beard, J.D., Rymer, J. \& Williams, D.L. (1989). An assessment system for collaborativewriting groups: Theory and empirical evaluation. Journal of Business and Technical Communication, 3(September), 29-51.

Bosley, D.S. (1990). Individual evaluations in a collaborative report project. Technical Communication, 37(May), 160-192.

Darian, J.C. (1988). Retail location decision making using a market potential approach: A group project. Journal of Marketing Education, 10(Summer), 79-84.

de los Santos, G. \& Jensen, T.D. (1985). Client-sponsored projects: Bridging the gap between theory and practice. Journal of Marketing Education, 23, 117-127.

Dixon, A.L., Gasenheimer, J.B. \& Barr, T.F. (2003). Identifying the lone wolf: A team perspective. Journal of Personal Selling and Sales Management, 24, 114-124. 
Dommeyer, C.J. (2012). "A new strategy for dealing with social loafers on the group project: The Segment Manager Method," Journal of Marketing Education, 34(2), 113 127.

Dommeyer, C.J. (2007). Using the diary method to deal with social loafers on the group project: Its effects on peer evaluations, group behavior, and attitudes. Journal of Marketing Education, 29, 175-188.

Dommeyer, C.J. (1986). A comparison of the individual proposal and the team project in the marketing research course. Journal of Marketing Education, 8(1), 30-38.

Forman, J. \& Katsky, P. (1986). The group report: A problem in small group or writing processes? The Journal of Business Communication, 8(Spring), 30-38.

Gackowski, Z.J. (2003). Case/real-life problem-based experimental learning with information system projects. Informing Science, June, 249-257.

Gardner, B.S. \& Korth, S.J. (1998). A framework for learning to work in teams. Journal of Education for Business, 74, 28-33.

Goldstein, J.R. and Malone, E.L. (1984). Journal of interpersonal and group communication: Facilitating technical project groups. Journal of Technical Writing and Communication, 14, 113-131.

Hansen, R.S. (2006). Benefits and problems with student teams: Suggestions for improving team projects. Journal of Education for Business, 82, 11-19.

Henke, J.W.Jr. (1985). Bring reality to the introductory marketing student. Journal of Marketing Education, 7 (Fall), 59-71.

Henke, J.W.Jr., Locander, W.B., Mentzer, J.T. \& Nastas. G.III (1988). Teaching techniques for the new marketing instructor: Bringing the business world into the classroom. Journal of Marketing Education, 10(Spring), 1-10.

Johnson, D.W. and Roger T. Johnson (1987). Learning Together and Alone: Cooperative, Competitive, and Individualistic Learning, $2^{\text {nd }}$ edition. Englewood Cliffs, NJ: PrenticeHall.

Johnson, D.W., Maruyama, G., Johnson, R.T., Nelson, D. \& Skon, L. (1981). Effects of cooperative, competitive, and individualistic goal structures on achievement: A metaanalysis. Psychological Bulletin, 89(January), 47-62.

Kohn, A. (1986). No Contest: The Case against Competition. Boston: Houghton Mifflin Company.

Kotler, P. \& Armstrong, G. (2016). Principles of Marketing, $16^{\text {th }}$ edition. Boston, MA: Pearson.

Larson, C.E. \& LaFasto, F.M.J. (1989). TeamWork: What Must Go Right/What Can Go Wrong. Newbury Park, CA: Sage.

Latane, B., Williams, K. \& Harkins, S. (1979). Many hands make light the work: The causes and consequences of social loafing. Journal of Personality and Social Psychology, 37, 822-832.

Nezlek, J.B., Wheeler, L. \& Reis, H.T. (1983). Studies of social participation. In Natuarlistic Approaches to Studying Social Interaction, edited by Reis, H.T. San Francisco: Jossey-Bass, pp. 57-73. 
Parsons, A.L. \& Lepkowska-White, E. (2009). Group projects using clients versus not using clients: Do students perceive any differences? Journal of Marketing Education, 31(2), 154-159.

Slavin, R.E. (1990). Cooperative Learning: Theory, Research, and Practice. Englewood, NJ: Prentice Hall.

Strong, J.T. (1988). Recommendations on how to improve the educational value of group projects in marketing curricula. In 1988 Southern Marketing Association Conference Proceedings. Atlanta, GA: Southern Marketing Association, pp. 317-322.

Strong, J.T. \& Anderson, R.E. (1990). Free-riding in group projects: Control mechanisms and preliminary data. Journal of Marketing Education, 12, 61-67.

Sundstrom, E., De Meuse, K.P. \& Futrell, D. (1990). Work team: Applications and effectiveness. American Psychologist, 45, 120-133.

Tyagi, P.K. (2010). Expectancy theory and social loafing in marketing research group projects. The Business Review, 14(2), 22-27.

Webb, N.M. (1982). Student interaction and learning in small groups. Review of Educational Research, 52(Fall), 421-445.

Williams, D., Beard, J.D. \& Rymer, J. (1991). Team projects: Achieving their full potential. Journal of Marketing Education, 13(1), 45-53. 